\title{
Protective effect of mitochondria-targeted peptide MTP-131 against oxidative stress-induced apoptosis in RGC-5 cells
}

\author{
MIN CHEN $^{1}$, BINGQIAN LIU ${ }^{2}$, JIAN MA ${ }^{1}$, JIAN GE $^{2}$ and KAIJUN WANG ${ }^{1}$ \\ ${ }^{1}$ Eye Center, The 2nd Affiliated Hospital, Medical College of Zhejiang University, Zhejiang Provincial \\ Key Lab of Ophthalmology, Hangzhou, Zhejiang 310009; ${ }^{2}$ State Key Laboratory of Ophthalmology, \\ Zhongshan Ophthalmic Center, Sun Yat-sen University, Guangzhou, Guangdong 510060, P.R. China
}

Received January 22, 2016; Accepted January 19, 2017

DOI: $10.3892 / \mathrm{mmr} .2017 .6271$

\begin{abstract}
The retina of the human eye is extremely vulnerable to oxidative damage. Previous studies have demonstrated that oxidative stress is the predominant mechanism associated with the pathogenesis of age-related macular degeneration, diabetic retinopathy, glaucoma and retinitis pigmentosa. MTP-131, a novel mitochondria-targeted peptide, has been demonstrated to specifically concentrate in the inner mitochondria membrane and to exhibit remarkable antioxidant effects both in vitro and in animal models. In the present study, the protective effect of MTP-131 was evaluated in response to hydrogen peroxide $\left(\mathrm{H}_{2} \mathrm{O}_{2}\right)$-induced oxidative damage in a retinal ganglion cell line, RGC-5. Cell viability was measured by lactate dehydrogenase (LDH) assay. Changes of mitochondrial membrane potential and generation of intracellular reactive oxygen species (ROS) were measured by flow cytometry and confocal microscopy, respectively. Annexin V-fluorescein isothiocyanate/propidium iodide staining was used for assessment of apoptosis. Release of cytochrome $\mathrm{c}$ was analyzed by confocal microscopy. Pretreatment of cells with MTP-131 inhibited $\mathrm{H}_{2} \mathrm{O}_{2}$-induced cytotoxicity and reduced $\mathrm{LDH}$ release in a dose-dependent manner, compared with cells treated with $\mathrm{H}_{2} \mathrm{O}_{2}$ alone. Mitochondrial depolarization and ROS generation were also prevented by MTP-131 pretreatment. In addition, MTP-131 pretreatment inhibited cytochrome $\mathrm{c}$ release from mitochondria to cytoplasm, and significantly reduced apoptosis in RGC-5 cells, compared with cells treated with $\mathrm{H}_{2} \mathrm{O}_{2}$ alone. In conclusion, mitochondria-targeted peptide MTP-131
\end{abstract}

Correspondence to: Dr Kaijun Wang, Eye Center, The 2nd Affiliated Hospital, Medical College of Zhejiang University, Zhejiang Provincial Key Lab of Ophthalmology, 88 Jiefang Road, Hangzhou, Zhejiang 310009, P.R. China

E-mail: kaijwang@126.com

Dr Jian Ge, State Key Laboratory of Ophthalmology, Zhongshan Ophthalmic Center, Sun Yat-sen University, 54 South Xianlie Road, Guangzhou, Guangdong 510060, P.R. China

E-mail: gejian@mail.sysu.edu.cn

Key words: retinal ganglion cell, mitochondria, oxidative stress, apoptosis, eye, antioxidants exhibited a protective effect against oxidative stress-induced apoptosis in RGC-5 cells, which may provide a novel approach for the treatment of age-associated retinal diseases.

\section{Introduction}

Previous studies have demonstrated the importance of mitochondria and oxidative stress in the development of neuronal diseases, such as Parkinson's disease (PD) and Alzheimer's disease $(1,2)$. In human eyes, the retina is extremely vulnerable to oxidative damage. Oxidative stress has been demonstrated to be the predominant mechanism associated with the pathogenesis of age-related macular degeneration (AMD), diabetic retinopathy (DR), glaucoma and retinitis pigmentosa (RP) (3-6). Novel strategies targeting mitochondria and reactive oxygen species (ROS) generation may provide promising prospects towards antioxidant therapy in these retinal diseases.

A novel mitochondria-targeted peptide, MTP-131 (also known as SS-31 or Bendavia), originally designed by Hazel H. Szeto and Peter W. Schiller (7), is a water-soluble peptide with an alternating aromatic cationic motif (D-Arg-dimethylTyr-Lys-Phe- $\mathrm{NH}_{2}$ ) and a $3+$ net charge at physiological $\mathrm{pH}$ (8). The fraction of the peptide partitioned to mitochondria has been estimated to be 1,000 to 5,000 -fold compared with the extra-mitochondrial concentration, and the peptide is predominately localized to the inner mitochondrial membrane (7). MTP-131 reduces ROS production in a dose-dependent manner and prevents oxidative damage in neuronal cell lines (9). In addition, treatment of mice with MTP-131 prevents loss of neurons and increases survival in PD and amyotrophic lateral sclerosis animal models (10).

Since MTP-131 has a unique mitochondria-targeted delivery, and exhibits potent antioxidant and neuroprotective effect both in vitro and in vivo, the present study aimed to evaluate the protective effect of MTP-131 against hydrogen peroxide $\left(\mathrm{H}_{2} \mathrm{O}_{2}\right)$-induced oxidative damage in RGC-5 cells.

\section{Materials and methods}

Reagents and chemicals. MTP-131 (D-Arg-(2'6'-dimethylTyr)Lys-Phe- $\mathrm{NH}_{2}$ ) was kindly provided by Stealth BioTherapeutics, Inc. (Newton, MA, USA). Gibco Dulbecco's modified Eagle's medium (DMEM) and fetal bovine serum (FBS) were 
obtained from Thermo Fisher Scientific (Waltham, MA, USA). Lactate dehydrogenase (LDH) assay kit was obtained from Roche Diagnostics Gmbh (Mannheim, Germany). Tetramethylrhodamine methyl ester perchlorate (TMRM), 2',7'-dichlorodihydrofluorescein diacetate ( $\left.\mathrm{H}_{2} \mathrm{DCFDA}\right)$ and MitoTracker Deep Red FM were obtained from Thermo Fisher Scientific, Inc. and prepared as $50 \mu \mathrm{M}, 1$ and $1 \mathrm{mM}$ stock solutions in dimethyl sulfoxide, respectively. Annexin V-fluorescein isothiocyanate (FITC)/propidium iodide (PI) apoptosis assay kit was from Multisciences Lianke Biotech Co., Ltd. (Hangzhou, China). Unless specified, all other reagents were obtained from Sigma-Aldrich; Merck KGaA (Darmstadt, Germany).

Cell culture. The RGC-5 cell line was kindly provided by Dr Zhiqun Tan (Department of Neurology, UC Irvine School of Medicine, Irvine, CA, USA). Undifferentiated RGC-5 cells were used in the present study. Cells were cultured in DMEM containing $10 \% \mathrm{FBS}$, and $1 \%$ penicillin-streptomycin (100 U/ml penicillin and $100 \mu \mathrm{g} / \mathrm{ml}$ streptomycin) at $37^{\circ} \mathrm{C}$ and $5 \% \mathrm{CO}_{2}$. Cells were passaged by trypsinization every 3 days. All cell culture dishes and plates were obtained from BD Biosciences (Franklin Lakes, NJ, USA).

MTP-131 pretreatment and induction of oxidative stress. RGC-5 cells were seeded at a density of $1 \times 10^{4}$ cells/well in 6-well plates and incubated in $5 \% \mathrm{CO}_{2}$ at $37^{\circ} \mathrm{C}$ for $24 \mathrm{~h}$. Cells at approximately $70 \%$ confluence were pretreated with 0.01 , 0.1 or $1 \mu \mathrm{M}$ MTP-131 in serum-free DMEM at $37^{\circ} \mathrm{C}$ for $1 \mathrm{~h}$ and then rinsed twice with PBS. Then, RGC-5 cells were exposed to $500 \mu \mathrm{M} \mathrm{H}_{2} \mathrm{O}_{2}$ in serum-free DMEM for $24 \mathrm{~h}$ to induce a sustained oxidative stress in vitro. Untreated cells and cells treated with $\mathrm{H}_{2} \mathrm{O}_{2}$ alone were used as normal and $\mathrm{H}_{2} \mathrm{O}_{2}$ control, respectively.

Measurement of cell viability. Cell viability was assessed by LDH assay using the Cytotoxicity Detection kitPLUS (Roche Diagnostics Gmbh) according to the manufacturer's instructions and as described previously (11). Briefly, RGC-5 cells were seeded in 96-well plates at a density of $5 \times 10^{3} /$ well, and treated as described above. Culture supernatant $(50 \mu \mathrm{l})$ from each well was transferred to a new 96-well plate and $100 \mu \mathrm{l}$ reaction mixture solution was added to each well. Following incubation at room temperature in the dark for $30 \mathrm{~min}, 50 \mu \mathrm{l}$ of stop solution was added to each well to terminate the reaction. Absorbance was measured using a microplate reader (Bio-Rad Laboratories, Inc., Hercules, CA, USA), at $490 \mathrm{~nm}$ test wavelength and at $630 \mathrm{~nm}$ reference wavelength. Cell viability was estimated as follows: cytotoxicity $(\%)=($ experimental value-low control) / (high control-low control) x100\%.

Measurement of mitochondrial membrane potential changes $(\Delta \Psi m)$. TMRM, a cationic fluorescent probe which is taken up by mitochondria in a potential-dependent manner, was used to evaluate $\Delta \Psi \mathrm{m}$, as described previously (9). To quantify $\Delta \Psi \mathrm{m}$ by flow cytometry, RGC-5 cells $\left(1 \times 10^{4}\right.$ cells/well in a 6 -well plate) were pretreated with $0.01,0.1$ or $1 \mu \mathrm{M}$ MTP-131 for $1 \mathrm{~h}$ and then incubated with $500 \mu \mathrm{M} \mathrm{H}_{2} \mathrm{O}_{2}$ for $2 \mathrm{~h}$. Cells were harvested and suspended in freshly prepared TMRM (200 nM) in phenol red and serum-free DMEM for $30 \mathrm{~min}$ at $37^{\circ} \mathrm{C}$ in the dark. All samples were rinsed twice with PBS and analyzed immediately by flow cytometry using a FACSAria II (BD Biosciences, Franklin Lakes, NJ, USA) and excitation/emission (ex/em) wavelengths 548/573 nm. A total of $1 \times 10^{4}$ cells were routinely collected, and results were expressed in arbitrary units as the mean fluorescence intensity (MFI) from the average of at least three separate experiments.

For confocal microscopy, RGC-5 cells were plated in Petri dishes. Following MTP-131 pretreatment and $\mathrm{H}_{2} \mathrm{O}_{2}$ incubation, cells were rinsed twice and loaded with freshly prepared $500 \mathrm{nM}$ TMRM for $30 \mathrm{~min}$ at $37^{\circ} \mathrm{C}$ in the dark. Following two rinses with PBS, cells were visualized by confocal microscopy using a LSM 510 microscope (Carl Zeiss AG, Oberkochen, Germany) and ex/m wavelengths 548/573 nm.

Measurement of intracellular ROS. Intracellular ROS in RGC-5 cells was measured with $\mathrm{H}_{2}$ DCFDA, as described previously (12). This nonfluorescent probe accumulates within cells and transforms into 2',7'-dichlorodihydrofluorescein $\left(\mathrm{H}_{2} \mathrm{DCF}\right)$ by deacetylation, which then reacts with ROS to form the fluorescent dichlorofluorescein (DCF). To quantify ROS by flow cytometry, RGC-5 cells $\left(1 \times 10^{4}\right.$ cells/well in a 6 -well plate) were pretreated with $0.01,0.1$ or $1 \mu \mathrm{M}$ MTP-131 for $1 \mathrm{~h}$ and then incubated with $500 \mu \mathrm{M} \mathrm{H}_{2} \mathrm{O}_{2}$ for $24 \mathrm{~h}$. Cells were harvested and suspended in freshly prepared $\mathrm{H}_{2}$ DCFDA $(5 \mu \mathrm{M})$ in phenol red and serum-free DMEM for $30 \mathrm{~min}$ at $37^{\circ} \mathrm{C}$ in the dark. All samples were rinsed twice with PBS and analyzed immediately by flow cytometry (ex/em: 488/530 nm). Ten thousand cells were routinely collected, and results were expressed as the MFI in arbitrary units from the average of at least three separate experiments.

For visualization by confocal microscopy, cells were plated in Petri dishes. Following pretreatment with MTP-131 and incubation with $\mathrm{H}_{2} \mathrm{O}_{2}, 5 \mu \mathrm{M}$ freshly prepared $\mathrm{H}_{2}$ DCFDA was added into cells and incubated at $37^{\circ} \mathrm{C}$ for $30 \mathrm{~min}$ in the dark. Following two rinses with PBS, cells were immediately imaged by confocal microscopy (ex/em: 495/525 nm).

Measurement of apoptosis. Apoptosis was measured using an Annexin V-FITC/PI apoptosis assay kit, according to the manufacturer's instructions. Briefly, cells were pretreated with $0.01,0.1$ or $1 \mu \mathrm{M}$ MTP-131 for $1 \mathrm{~h}$ and then incubated with $500 \mu \mathrm{M} \mathrm{H}_{2} \mathrm{O}_{2}$ for 4, 8, 12 and $24 \mathrm{~h}$. To quantify apoptosis by flow cytometry, cells were collected by trypsinization and centrifugation (100 x $g$ for $5 \mathrm{~min}$, at room temperature) at the appropriate time point. Following two rinses with PBS, cells were resuspended in $500 \mu 1$ loading buffer and incubated with $5 \mu \mathrm{l}$ Annexin $\mathrm{V}$ and $10 \mu \mathrm{l} \mathrm{PI}$ at room temperature for 5 min in the dark. Flow cytometry analysis was immediately performed (ex/em: 488/530 nm), using a FITC signal detector (FL1 channel) and PI emission signal detector (FL2 channel) to analyze Annexin V-FITC binding and PI staining, respectively. A total of $1 \times 10^{4}$ cells were collected and divided into four groups: viable cells (Annexin $\mathrm{V}^{-} / \mathrm{PI}^{-}, \mathrm{Q} 3$ ), early apoptotic cells (Annexin $\left.\mathrm{V}^{+} / \mathrm{PI}^{-}, \mathrm{Q} 4\right)$, late apoptotic cells (Annexin $\mathrm{V}^{+} / \mathrm{PI}^{+}, \mathrm{Q} 2$ ) or dead cells (Annexin $\mathrm{V}^{-} / \mathrm{PI}^{+}, \mathrm{Q} 1$ ). The apoptotic rate was calculated as the sum of the percentages of early apoptotic cells (Q4) and late apoptotic cells (Q2).

Measurement of cytochrome c release. The release of cytochrome $\mathrm{c}$ from mitochondria to the cytoplasm was measured 
by confocal microscopy as previously described (13). Briefly, cells were seeded onto Fisherbrand cover glass (Thermo Fisher Scientific, Inc.) at a density of 2,000 cells/chamber. Following pretreatment with $1 \mu \mathrm{M}$ MTP-131 for $1 \mathrm{~h}$, cells were incubated in the presence or absence of $500 \mu \mathrm{M} \mathrm{H}_{2} \mathrm{O}_{2}$ for $6 \mathrm{~h}$ at $37^{\circ} \mathrm{C}$ in $5 \% \mathrm{CO}_{2}$. Freshly prepared MitoTracker $(500 \mathrm{~nm})$ was added to the cells and incubated for $30 \mathrm{~min}$, just before the end of the $6 \mathrm{~h}$ incubation period. Cells were rinsed twice with PBS and fixed in $4 \%$ paraformaldehyde for $15 \mathrm{~min}$, followed by $5 \mathrm{~min}$ permeabilization with methanol on ice. Following blocking with $5 \%$ bovine serum albumin (BSA, Jackson ImmunoResearch Europe Ltd. Suffolk, UK) for $30 \mathrm{~min}$, cells were incubated with mouse monoclonal anti-cytochrome c antibody (sc-4280; 1:100, diluted with $1 \%$ BSA; Santa Cruz Biotechnology, Inc., Dallas, TX, USA) at $4^{\circ} \mathrm{C}$ overnight. Following three rinses with PBS, cells were incubated with DyLight 488-conjugated goat anti-mouse immunoglobulin $\mathrm{G}$ antibody (85-11-4011-85; 1:500, diluted with 1\% BSA; Multisciences Lianke Biotech Co., Ltd.) for $30 \mathrm{~min}$ at $37^{\circ} \mathrm{C}$ in the dark. Finally, cells were stained with Hoechst 33342 (1:1,000, Thermo Fisher Scientific, Inc.) for $5 \mathrm{~min}$, washed and mounted with anti-fade fluorescence mounting medium (Applygen Technologies, Inc., Beijing, China). Images were visualized by confocal microscopy. Translocation of cytochrome $\mathrm{c}$ from mitochondria to cytoplasm was analyzed by overlapping staining of cytochrome c and MitoTracker. In each group, six slides were selected and five fields of view from each were assessed.

Analysis of cell morphology. RGC-5 cells were seeded at a density of $1 \times 10^{4}$ cells/well on a 6 -well plate. Following pretreatment with $1 \mu \mathrm{M}$ MTP-131 for $1 \mathrm{~h}$ and subsequent treatment with $500 \mu \mathrm{M} \mathrm{H}_{2} \mathrm{O}_{2}$ for $24 \mathrm{~h}$, micrographs of all cultures were captured using a Zeiss LSM 510 Cell Observer system (Carl Zeiss, AG) to examine changes in cell morphology.

Statistical analysis. All assays were performed in at least three independent experiments and data are presented as the mean + standard error of the mean. Statistical analysis was performed by one-way analysis of variance and Newman-Keuls multiple comparison test, using GraphPad Prism 5.0 software (GraphPad Software Inc., La Jolla, CA, USA). P<0.05 was considered to indicate a statistically significant difference.

\section{Results}

MTP-131 treatment reduces $\mathrm{H}_{2} \mathrm{O}_{2}$-induced $L D H$ release in $R G C-5$ cells. $\mathrm{LDH}$ assay was performed to assess cell viability in RGC-5 cells following $\mathrm{H}_{2} \mathrm{O}_{2}$-induced sustained oxidative stress. Incubation with $500 \mu \mathrm{M} \mathrm{H}_{2} \mathrm{O}_{2}$ for $24 \mathrm{~h}$ resulted in loss of cell viability compared with untreated cells, and the percentage of $\mathrm{LDH}$ release was $28.62 \pm 2.94 \%$ relative to the untreated cells (Fig. 1). Pretreatment with 1, 0.1 and $0.01 \mu \mathrm{M}$ MTP-131 reduced LDH release in a dose-dependent manner compared to cells treated with $\mathrm{H}_{2} \mathrm{O}_{2}$ alone, with $\mathrm{LDH}$ release measured at $6.05 \pm 0.44,13.08 \pm 0.53$ and $22.39 \pm 1.73 \%$ relative to the untreated cells, respectively $(\mathrm{P}<0.01, \mathrm{P}<0.01$ and $\mathrm{P}<0.05$, respectively, compared with $\mathrm{H}_{2} \mathrm{O}_{2}$ alone; Fig. 1).

MTP-131 treatment prevents $\mathrm{H}_{2} \mathrm{O}_{2}$-induced mitochondrial depolarization. RGC-5 cells were pretreated with $1 \mu \mathrm{M}$

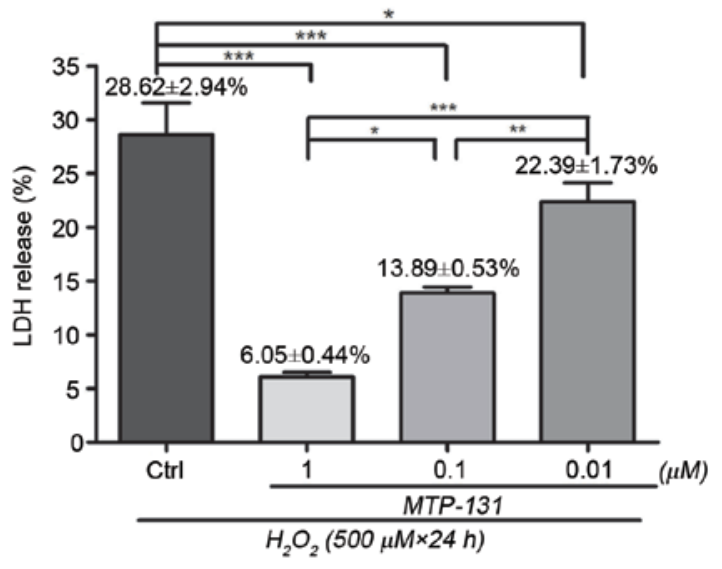

Figure 1. MTP-131 treatment reduces $\mathrm{H}_{2} \mathrm{O}_{2}$-induced LDH release in RGC-5 cells. RGC- 5 cells were pretreated with $1,0.1$ or $0.01 \mu \mathrm{M}$ MTP-131 for $1 \mathrm{~h}$, then incubated with $500 \mu \mathrm{M} \mathrm{H}_{2} \mathrm{O}_{2}$ for $24 \mathrm{~h}$. RGC-5 cells treated with $\mathrm{H}_{2} \mathrm{O}_{2}$ alone were used as the control. Viability was calculated as the $\mathrm{LDH}$ release \% increase over untreated RGC-5 cells. ${ }^{*} \mathrm{P}<0.05,{ }^{* *} \mathrm{P}<0.01$ and ${ }^{* * *} \mathrm{P}<0.001$, with comparisons indicated by lines. MTP, mitochondria-targeted peptide; LDH, lactate dehydrogenase; $\mathrm{H}_{2} \mathrm{O}_{2}$, hydrogen peroxide.

MTP-131 for $1 \mathrm{~h}$, and then incubated with $500 \mu \mathrm{M} \mathrm{H}_{2} \mathrm{O}_{2}$ for $2 \mathrm{~h}$. TMRM, a lipophilic cation which accumulates in mitochondria in a manner dependent on the membrane potential, was used to demonstrate $\Delta \Psi \mathrm{m}$ in RGC-5 cells. As expected, untreated RGC-5 cells with healthy mitochondrial membrane potential exhibited high fluorescence intensity for TMRM (Fig. 2A, left panel), while incubation with $500 \mu \mathrm{M} \mathrm{H}_{2} \mathrm{O}_{2}$ alone for $2 \mathrm{~h}$ led to mitochondrial depolarization, resulting in loss of the TMRM dye from the mitochondria and a decrease in fluorescence intensity (Fig. 2A, middle panel). Pretreatment of the cells with $1 \mu \mathrm{M}$ MTP-131 for $1 \mathrm{~h}$, however, inhibited $\mathrm{H}_{2} \mathrm{O}_{2}$-induced mitochondria depolarization, as evidenced by the higher fluorescence intensity of TMRM in the MTP-131-treated cells (Fig. 2A, right panel) compared with the cells treated with $\mathrm{H}_{2} \mathrm{O}_{2}$ alone. Flow cytometry analysis confirmed that pretreatment with MTP-131 significantly prevented $\mathrm{H}_{2} \mathrm{O}_{2}$-induced mitochondria depolarization in a dose-dependent manner, compared with cells treated with $\mathrm{H}_{2} \mathrm{O}_{2}$ alone (Fig. 2B and C).

MTP-131 treatment inhibits $\mathrm{H}_{2} \mathrm{O}_{2}$-induced intracellular $\mathrm{ROS}$ production. RGC-5 cells were pretreated with $1 \mu \mathrm{M}$ MTP-131 for $1 \mathrm{~h}$, then incubated with $500 \mu \mathrm{M} \mathrm{H}_{2} \mathrm{O}_{2}$ for $24 \mathrm{~h}$. Cells were then loaded with $\mathrm{H}_{2}$ DCFDA for $30 \mathrm{~min}$ and DCF fluorescence was measured by flow cytometry and confocal microscopy. As demonstrated in Fig. 3A, incubation with $\mathrm{H}_{2} \mathrm{O}_{2}$ increased $\mathrm{ROS}$ production, as evidenced by the elevated DCF fluorescence intensity in the $\mathrm{H}_{2} \mathrm{O}_{2}$-treated cells (middle panel) compared with the untreated cells (left panel). Pretreatment with MTP-131, however, inhibited $\mathrm{H}_{2} \mathrm{O}_{2}$-induced $\mathrm{ROS}$ production, as evidenced by the lower DCF fluorescence intensity in MTP-131-treated cells (right panel; Fig. 3A) compared with the $\mathrm{H}_{2} \mathrm{O}_{2}$-treated cells (middle panel; Fig. 3A). Flow cytometry analysis further confirmed that pretreatment with MTP-131 reduced ROS generation in RGC-5 cells in a dose-dependent manner compared with cells treated with $\mathrm{H}_{2} \mathrm{O}_{2}$ alone (Fig. 3B and C).

MTP-131 treatment protects against $\mathrm{H}_{2} \mathrm{O}_{2}$-induced apoptosis. Apoptosis was measured by Annexin V-FITC/PI staining and 
Table I. Summary of flow cytometry data measuring apoptosis.

\begin{tabular}{|c|c|c|c|c|c|c|}
\hline \multirow[b]{2}{*}{ Time point } & \multirow[b]{2}{*}{ Quadrant } & \multirow[b]{2}{*}{ RGC-5 } & \multirow[b]{2}{*}{$\mathrm{H}_{2} \mathrm{O}_{2}(500 \mu \mathrm{M})$} & \multicolumn{3}{|c|}{$\mathrm{H}_{2} \mathrm{O}_{2}(500 \mu \mathrm{M})+\mathrm{MTP}-131(\mu \mathrm{M})$} \\
\hline & & & & 1 & 0.1 & 0.01 \\
\hline \multirow[t]{4}{*}{$4 \mathrm{~h}$} & Q3 & $94.50 \pm 0.10$ & $81.27 \pm 0.50$ & $93.27 \pm 0.59^{\mathrm{a}}$ & $94.33 \pm 0.45^{\mathrm{a}}$ & $92.40 \pm 0.09^{\mathrm{a}}$ \\
\hline & Q4 & $0.90 \pm 0.06$ & $13.77 \pm 0.38$ & $0.83 \pm 0.03^{\mathrm{a}}$ & $0.93 \pm 0.06^{\mathrm{a}}$ & $0.77 \pm 0.09^{a}$ \\
\hline & Q2 & $3.93 \pm 0.30$ & $4.80 \pm 0.15$ & $4.56 \pm 0.50$ & $4.20 \pm 0.42$ & $5.07 \pm 0.13$ \\
\hline & $\mathrm{Q} 2+\mathrm{Q} 4$ & $4.83 \pm 0.24$ & $18.57 \pm 0.45$ & $5.40 \pm 0.47^{\mathrm{a}}$ & $5.13 \pm 0.48^{\mathrm{a}}$ & $5.83 \pm 0.22^{\mathrm{a}}$ \\
\hline \multirow[t]{4}{*}{$8 \mathrm{~h}$} & Q3 & $93.80 \pm 0.74$ & $81.30 \pm 1.01$ & $95.07 \pm 0.58^{\mathrm{a}}$ & $90.93 \pm 1.17^{\mathrm{a}}$ & $91.37 \pm 0.75^{a}$ \\
\hline & Q4 & $0.53 \pm 0.03$ & $15.40 \pm 0.90$ & $0.57 \pm 0.09^{\mathrm{a}}$ & $0.67 \pm 0.12^{\mathrm{a}}$ & $0.47 \pm 0.09^{a}$ \\
\hline & Q2 & $4.60 \pm 0.70$ & $3.20 \pm 0.40$ & $3.93 \pm 0.57$ & $7.70 \pm 0.85^{\mathrm{b}}$ & $7.47 \pm 0.92^{b}$ \\
\hline & $\mathrm{Q} 2+\mathrm{Q} 4$ & $5.13 \pm 0.73$ & $18.60 \pm 1.01$ & $4.50 \pm 0.57^{\mathrm{a}}$ & $8.37 \pm 0.93^{\mathrm{a}}$ & $7.93 \pm 0.96^{\mathrm{a}}$ \\
\hline \multirow[t]{4}{*}{$12 \mathrm{~h}$} & Q3 & $91.40 \pm 0.30$ & $75.20 \pm 1.99$ & $93.00 \pm 0.31^{\mathrm{a}}$ & $93.00 \pm 1.11^{\mathrm{a}}$ & $75.70 \pm 0.55$ \\
\hline & Q4 & $0.53 \pm 0.17$ & $17.03 \pm 0.22$ & $0.63 \pm 0.07^{\mathrm{a}}$ & $0.53 \pm 0.07^{\mathrm{a}}$ & $17.63 \pm 1.17$ \\
\hline & Q2 & $5.67 \pm 0.52$ & $7.67 \pm 1.88$ & $5.10 \pm 0.25$ & $5.50 \pm 0.92$ & $6.57 \pm 1.45$ \\
\hline & Q2+Q4 & $6.20 \pm 0.68$ & $24.70 \pm 1.99$ & $5.73 \pm 0.28^{\mathrm{a}}$ & $6.03 \pm 0.98^{\mathrm{a}}$ & $24.20 \pm 0.60$ \\
\hline \multirow[t]{4}{*}{$24 \mathrm{~h}$} & Q3 & $93.30 \pm 1.20$ & $58.97 \pm 0.56$ & $93.77 \pm 0.46^{a}$ & $91.87 \pm 0.96^{\mathrm{a}}$ & $60.10 \pm 3.38$ \\
\hline & Q4 & $0.90 \pm 0.02$ & $34.10 \pm 2.96$ & $1.20 \pm 0.17$ & $1.37 \pm 0.17$ & $34.73 \pm 2.19$ \\
\hline & Q2 & $4.87 \pm 1.11$ & $6.93 \pm 2.85$ & $4.43 \pm 0.52$ & $6.27 \pm 0.95$ & $5.13 \pm 1.53$ \\
\hline & Q2+Q4 & $5.76 \pm 1.23$ & $41.03 \pm 0.56$ & $5.63 \pm 0.54^{\mathrm{a}}$ & $7.63 \pm 0.90^{\mathrm{a}}$ & $39.87 \pm 3.38$ \\
\hline
\end{tabular}

Data are presented as mean \% of total cells \pm standard error of mean. ${ }^{\mathrm{a}} \mathrm{P}<0.001$ and ${ }^{\mathrm{b}} \mathrm{P}<0.01$ compared with $\mathrm{RGC}-5$ cells treated with $\mathrm{H}_{2} \mathrm{O}_{2}$ alone (by one-way analysis of variance). $\mathrm{H}_{2} \mathrm{O}_{2}$, hydrogen peroxide; MTP, mitochondria-targeted peptide; Q3, viable cells; Q4, early apoptotic cells; Q2, late apoptotic cells.

flow cytometry analysis. RGC-5 cells were pretreated with MTP-131 for $1 \mathrm{~h}$ and then incubated with $500 \mu \mathrm{M} \mathrm{H}_{2} \mathrm{O}_{2}$ for $4,8,12$ and $24 \mathrm{~h}$. Following incubation with $\mathrm{H}_{2} \mathrm{O}_{2}$, the survival rate of RGC-5 cells decreased in a time-dependent manner compared with untreated cells (Fig. 4 and Table I). Pretreatment with 1 and $0.1 \mu \mathrm{M}$ MTP-131 inhibited $\mathrm{H}_{2} \mathrm{O}_{2}$-induced apoptosis at 4, 8, 12 and $24 \mathrm{~h}$ compared with cells treated with $\mathrm{H}_{2} \mathrm{O}_{2}$ alone at the same time points $(\mathrm{P}<0.001$ compared with $\mathrm{H}_{2} \mathrm{O}_{2}$ alone; Fig. 4 and Table I). Pretreatment with $0.01 \mu \mathrm{M}$ MTP-131 also alleviated apoptosis at 4 and $8 \mathrm{~h}$ following $\mathrm{H}_{2} \mathrm{O}_{2}$ incubation, but no effect was observed at 12 and $24 \mathrm{~h}$ compared with cells treated with $\mathrm{H}_{2} \mathrm{O}_{2}$ alone (Fig. 4 and Table I).

MTP-131 treatment inhibits $\mathrm{H}_{2} \mathrm{O}_{2}$-induced release of cytochrome c from mitochondria to cytoplasm. The release of cytochrome $\mathrm{c}$ from mitochondria into the cytoplasm was examined by confocal microscopy. As demonstrated in Fig. 5, no release of cytochrome c (green fluorescence signal) from mitochondria (red fluorescence signal) was evident in untreated RGC-5 control cells (upper panels). Incubation with $500 \mu \mathrm{M} \mathrm{H}_{2} \mathrm{O}_{2}$ for $6 \mathrm{~h}$, however, resulted in enhanced cytochrome c staining in the cytoplasm of RGC-5 cells (middle panels) compared with the untreated RGC-5 cells (Fig. 5), indicating that $\mathrm{H}_{2} \mathrm{O}_{2}$ induced the release of cytochrome $\mathrm{c}$ from mitochondria to cytoplasm. Pretreatment with $1 \mu \mathrm{M}$ MTP-131 for $1 \mathrm{~h}$ inhibited the $\mathrm{H}_{2} \mathrm{O}_{2}$-induced release of cytochrome c, as evidenced by the decreased cytochrome c (green) fluorescent staining in MTP-131-treated cells (lower panels) compared with cells treated with $\mathrm{H}_{2} \mathrm{O}_{2}$ alone (Fig. 5).
MTP-131 treatment alleviates $\mathrm{H}_{2} \mathrm{O}_{2}$-induced morphological changes in RGC-5 cells. Morphological changes in RGC-5 cells were analyzed by phase contrast microscopy. As demonstrated in Fig. 6, normal untreated RGC-5 cells exhibit a neuron-like appearance, with thin axons extending from the cell bodies (left panel). However, following incubation with $500 \mu \mathrm{M} \mathrm{H}_{2} \mathrm{O}_{2}$ for $24 \mathrm{~h}$, most cells exhibited a degenerative appearance, evidenced by the presence of vacuolar cell bodies and shrinkage of the axons (middle panel, Fig. 6) compared with the untreated cells. Pretreatment with $1 \mu \mathrm{M}$ MTP-131 prevented the $\mathrm{H}_{2} \mathrm{O}_{2}$-induced morphological changes, with MTP-131-treated cells maintaining a relatively healthy appearance, with flat cell bodies and regular axon extensions (right panel, Fig. 6).

\section{Discussion}

In the present study, the antioxidant effect of MTP-131 against $\mathrm{H}_{2} \mathrm{O}_{2}$-induced sustained oxidative stress was examined in undifferentiated RGC-5 cells. The present findings demonstrated that MTP-131 treatment prevented mitochondrial depolarization, decreased intracellular ROS production, and inhibited apoptosis induced by sustained oxidative stress in RGC-5 cells.

$\mathrm{H}_{2} \mathrm{O}_{2}$ is widely used to induce oxidative stress in experimental studies, leading to an increase in intracellular accumulation of ROS and RGC apoptosis (14-16). In the present study, $\mathrm{H}_{2} \mathrm{O}_{2}(500 \mu \mathrm{M}$ for $24 \mathrm{~h})$ was used to induce a sustained oxidative stress, and was demonstrated to cause significant cell damage in RGC-5 cells, which is consistent 

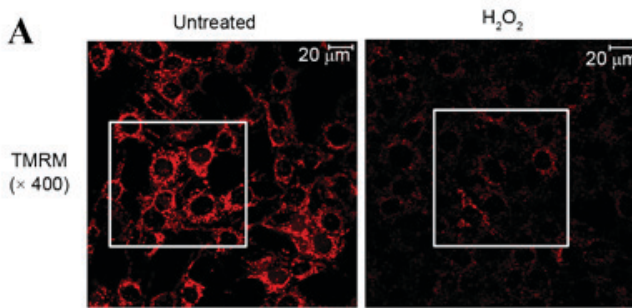

$\operatorname{MTP}-131(1 \mu \mathrm{M})+\mathrm{H}_{2} \mathrm{O}_{2}$
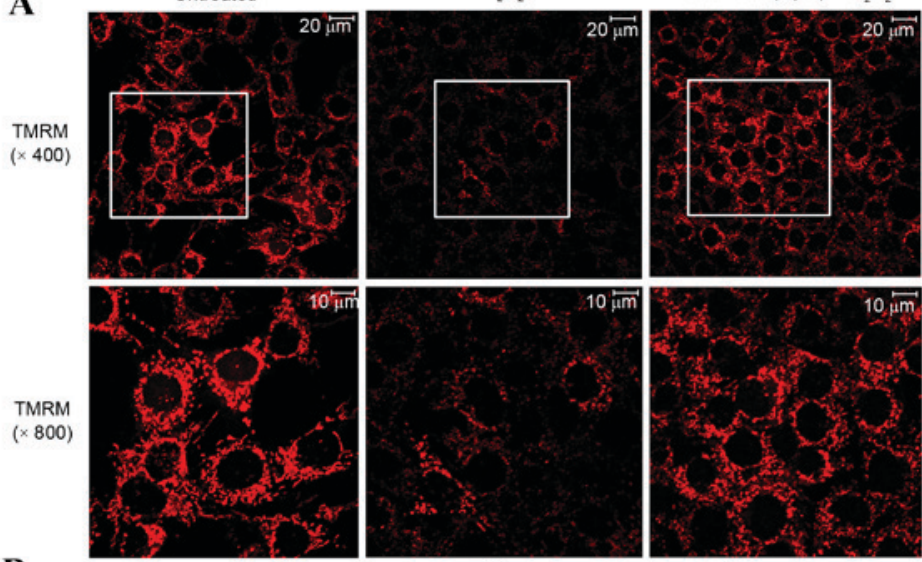

B

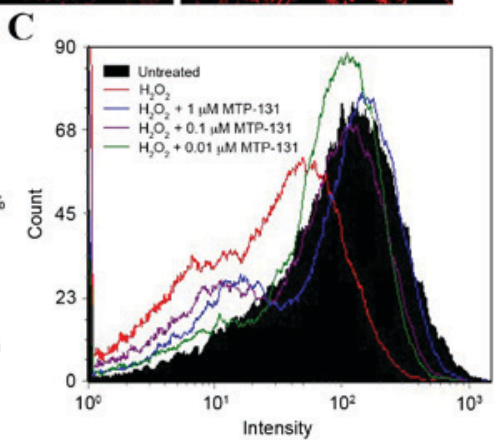

Figure 2. MTP-131 treatment prevents $\mathrm{H}_{2} \mathrm{O}_{2}$-induced mitochondrial depolarization. RGC-5 cells were pretreated with MTP-131 for $1 \mathrm{~h}$, then incubated with $500 \mu \mathrm{M} \mathrm{H}_{2} \mathrm{O}_{2}$ for $2 \mathrm{~h}$. Cells were then loaded with TMRM and measured by confocal microscopy and flow cytometry. Untreated RGC-5 cells and cells treated with $\mathrm{H}_{2} \mathrm{O}_{2}$ alone were used as controls. (A) Representative images from confocal microscopic analysis of (left panels) untreated RGC-5 cells, (middle panels) cells treated with $\mathrm{H}_{2} \mathrm{O}_{2}$ alone and (right panels) cells treated with $1 \mu \mathrm{M}$ MTP-131 and $\mathrm{H}_{2} \mathrm{O}_{2}$. Upper images: Original magnification, $\mathrm{x} 400$. Lower images are enlargements of segments of the upper images denoted by the white boxes. (B) Quantification of $\Delta \Psi \mathrm{m}(\%$ relative to the untreated RGC-5 cells) as measured by flow cytometry. Data represent mean values from three independent experiments. ${ }^{* * * *} \mathrm{P}<0.001 \mathrm{vs} . \mathrm{H}_{2} \mathrm{O}_{2}$ alone control. (C) Overlay of representative one-dimensional histograms from one flow cytometry experiment. MTP, mitochondria-targeted peptide; $\mathrm{H}_{2} \mathrm{O}_{2}$, hydrogen peroxide; TMRM, tetramethylrhodamine methyl ester perchlorate; $\Delta \Psi \mathrm{m}$, mitochondrial membrane potential change.
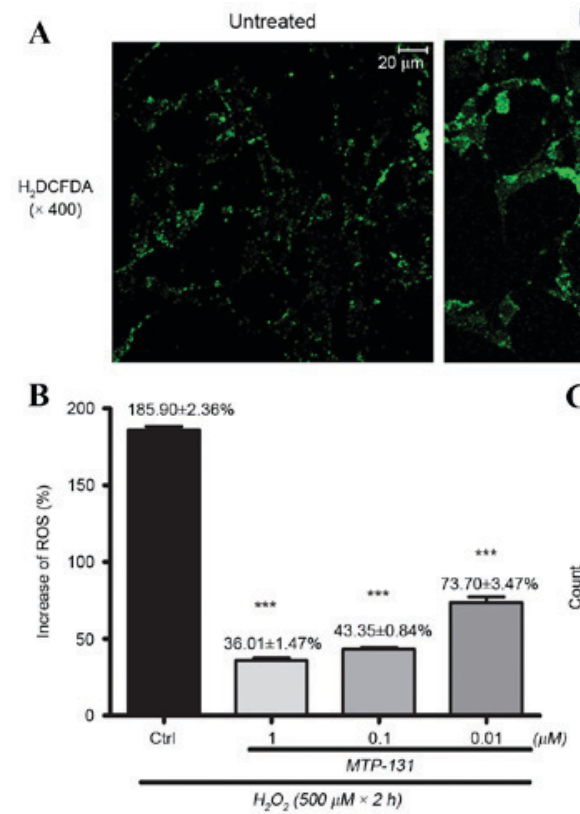

$\mathrm{H}_{2} \mathrm{O}_{2}$

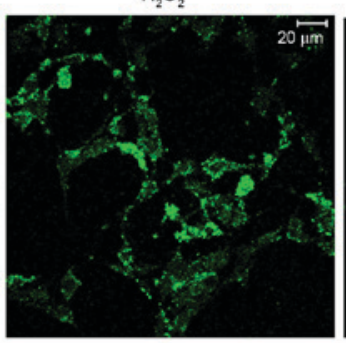

C

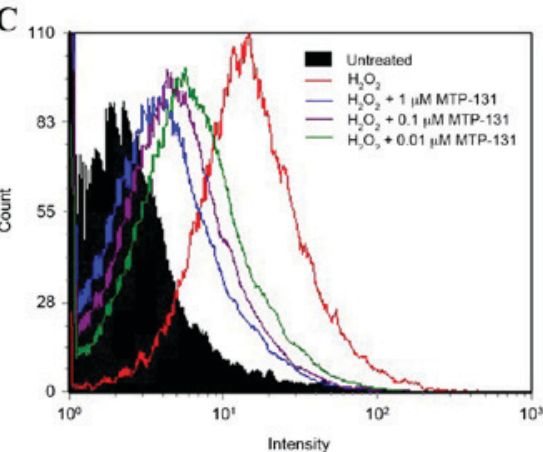

Figure 3. MTP-131 treatment inhibits $\mathrm{H}_{2} \mathrm{O}_{2}$-induced intracellular ROS production. RGC-5 cells were pretreated with MTP- 131 for $1 \mathrm{~h}$, and then incubated with $500 \mu \mathrm{M} \mathrm{H}_{2} \mathrm{O}_{2}$ for $24 \mathrm{~h}$. Cells were loaded with $\mathrm{H}_{2}$ DCFDA and DCF fluorescence was measured by confocal microscopy and flow cytometry. Untreated RGC-5 cells and cells treated with $\mathrm{H}_{2} \mathrm{O}_{2}$ alone were used as controls. (A) Confocal microscopic analysis of (left panel) untreated RGC-5 cells, (middle panel) cells treated with $\mathrm{H}_{2} \mathrm{O}_{2}$ alone and (right panels) cells treated with $1 \mu \mathrm{M}$ MTP-131 and $\mathrm{H}_{2} \mathrm{O}_{2}$. Original magnification, x400. (B) Quantification of ROS (\%) relative to the untreated RGC-5 cell control. MTP-131 pretreatment dose-dependently reduced $\mathrm{H}_{2} \mathrm{O}_{2}$-induced intracellular $\mathrm{ROS}$ production. ${ }^{* * *} \mathrm{P}<0.001$ vs. $\mathrm{H}_{2} \mathrm{O}_{2}$ alone control. (C) Overlay of representative one-dimensional histograms from one flow cytometry. MTP, mitochondria-targeted peptide; $\mathrm{H}_{2} \mathrm{O}_{2}$, hydrogen peroxide; ROS, reactive oxygen species; $\mathrm{H}_{2}$ DCFDA, 2',7'-dichlorodihydrofluorescein diacetate; DCF, dichlorofluorescein. 

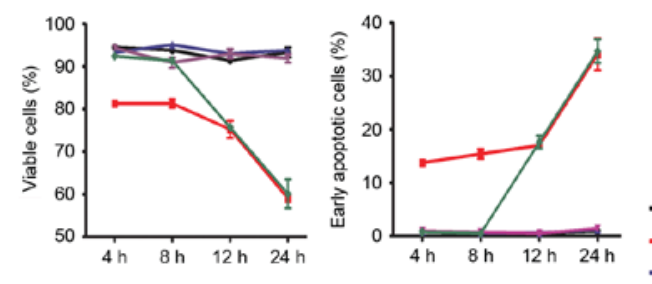
* Untreated
$+\mathrm{H}_{2} \mathrm{O}_{2}$
$+\mathrm{H}_{2} \mathrm{O}_{2}+1 \mu \mathrm{M}$ MTP-131
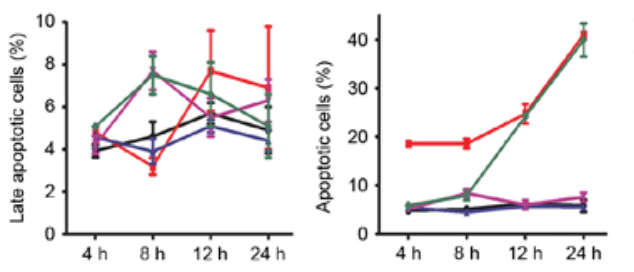

$+\mathrm{H}_{2} \mathrm{O}_{2}+0.1 \mu \mathrm{M}$ MTP -131

$+\mathrm{H}_{2} \mathrm{O}_{2}+0.01 \mu \mathrm{M}$ MTP-131

Figure 4. MTP-131 treatment reduces $\mathrm{H}_{2} \mathrm{O}_{2}$-induced apoptosis in RGC-5 cells. RGC-5 cells were pretreated with $1,0.1$ and $0.01 \mu \mathrm{M}$ MTP-131 for $1 \mathrm{~h}$, and then incubated with $500 \mu \mathrm{M} \mathrm{H}_{2} \mathrm{O}_{2}$ for 4, 8, 12 and $24 \mathrm{~h}$. Apoptosis was evaluated by flow cytometry analysis at the indicated time points. Untreated RGC-5 cells and cells treated with $\mathrm{H}_{2} \mathrm{O}_{2}$ alone were used as controls. Data are presented as mean $\%$ of total cells from three independent experiments. A detailed description of all data resulted from the apoptosis experiments is listed in Table $\mathrm{I}_{\text {. }} \mathrm{H}_{2} \mathrm{O}_{2}$, hydrogen peroxide; MTP, mitochondria-targeted peptide.

with previous studies (14). MTP-131 pretreatment protected RGC-5 cells from mitochondrial membrane depolarization, reduced ROS production and inhibited cytochrome $\mathrm{c}$ release from mitochondria to cytoplasm. These effects were demonstrated to alleviate apoptosis in RGC-5 cells, thus suggesting that MTP-131 exhibited a potential protective effect against oxidative stress in RGC-5 cells through direct inhibition of mitochondria-mediated pathways.

RGC-5 cells have been widely used in in vitro experimental studies (17-19). However, the validity of this cell line is now questioned. It has been demonstrated that the RGC-5 cell line is of mouse origin, not rat as it was first described, and that it express photoreceptor markers instead of retinal ganglion markers $(20,21)$. However, RGC-5 cells still have several properties in common with retinal progenitor cells and is therefore appropriate for neuronal cell studies (20). A series of retinal disorders have been related to oxidative damage, such as AMD, DR and RP $(3,4,6)$. The retina is constantly exposed to visible light, which makes it extremely vulnerable to oxidative damage, due to its great energy demands and high oxygen consumption (5). A previous study have demonstrated that oxidative stress is extremely important in the retinal pigment epithelium (RPE) cells. ROS induces mitochondrial dysfunction in RPE, leading to RPE cell apoptosis and death of photoreceptor cells (22).

Compared with traditional antioxidants, MTP-131 represents the only known class of cell-permeable compounds that specifically concentrates in the inner mitochondrial membrane (7). With a 3+ net charge, MTP-131 selectively binds to cardiolipin and modulates its interaction with cytochrome c. By inhibiting the cytochrome c/cardiolipin complex peroxidase activity, MTP-131 optimizes mitochondrial electron transport and ATP synthesis $(23,24)$. Numerous in vitro and animal studies have demonstrated the remarkable efficacy of MTP-131 in age-associated diseases. For example, daily treatment with MTP-131 reverses mitochondrial dysfunction and inhibits neuronal apoptosis and inflammation in mice with sepsis-associated encephalopathy (25). In addition, MTP-131 exhibits protective effects against cardiac ischemia-reperfusion injury (26). The effectiveness of cardiolipin combined

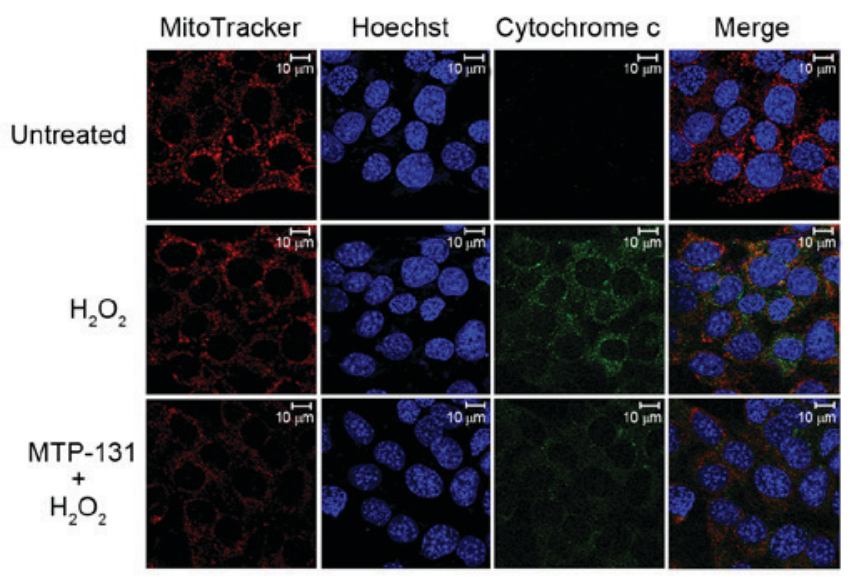

Figure 5. MTP-131 treatment inhibits $\mathrm{H}_{2} \mathrm{O}_{2}$-induced cytochrome c release from mitochondria to cytoplasm. RGC-5 cells were pretreated with $1 \mu \mathrm{M}$ MTP-131 for $1 \mathrm{~h}$, and then incubated with $500 \mu \mathrm{M} \mathrm{H}_{2} \mathrm{O}_{2}$ for $6 \mathrm{~h}$. MitoTracker (red) was used to label mitochondria, Hoechst 33342 was used to label nuclei (blue) and immunostaining with a specific antibody was used to detect cytochrome c (green). Representative images from confocal microscopic analysis are depicted here for untreated RGC-5 cells (upper panels), cells treated with $\mathrm{H}_{2} \mathrm{O}_{2}$ alone (middle panels) and cells pretreated with MTP-131 (lower panels). $\mathrm{H}_{2} \mathrm{O}_{2}$, hydrogen peroxide; MTP, mitochondria-targeted peptide.

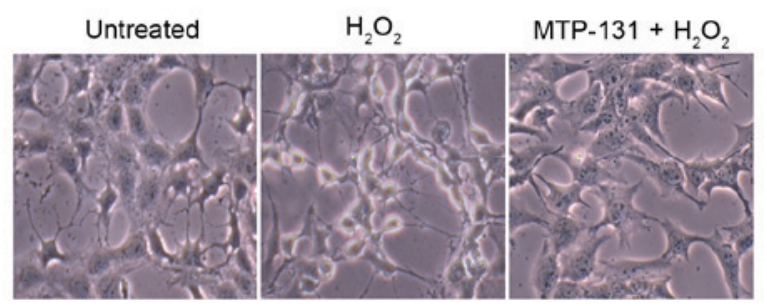

Figure 6. MTP-131 treatment alleviates $\mathrm{H}_{2} \mathrm{O}_{2}$-induced morphological changes in RGC-5 cells. RGC-5 cells were pretreated with $1 \mu \mathrm{M}$ MTP-131 for $1 \mathrm{~h}$ and then incubated with $500 \mu \mathrm{M} \mathrm{H}_{2} \mathrm{O}_{2}$ for $24 \mathrm{~h}$. Untreated RGC-5 cells and cells treated with $\mathrm{H}_{2} \mathrm{O}_{2}$ alone were used as controls. Representative images are depicted here from phase contrast light microscopy analysis (original magnification, x20). $\mathrm{H}_{2} \mathrm{O}_{2}$, hydrogen peroxide; MTP, mitochondria-targeted peptide.

with MTP-131 is currently being evaluated in a multinational clinical trial for reperfusion injury in patients with acute 
coronary events (ClinicalTrials.gov Identifier: NCT01572909), and a Phase 2 trial is underway assessing the effectiveness of MTP-131 on improving renal function following angioplasty for severe renal artery stenosis (ClinicalTrials.gov Identifier: NCT01755858) (27). Since MTP-131 has a unique mitochondria-targeted delivery, and exhibits potent antioxidant and neuroprotective effects both in vitro and in vivo, the present study aimed to evaluate the protective effect of MTP-131 against $\mathrm{H}_{2} \mathrm{O}_{2}$-induced oxidative damage in RGC-5 cells. The present findings demonstrated that MTP-131 inhibited $\mathrm{H}_{2} \mathrm{O}_{2}$-induced mitochondria depolarization, reduced intracellular ROS and prevented apoptosis in RGC-5 cells.

In conclusion, this novel class of targeted peptide therapeutics, including MTP-131, has the potential to restore mitochondrial bioenergetics. Further studies using animal models will be needed in order to fully explore this novel antioxidant approach for the treatment of age-related retinal diseases.

\section{Acknowledgements}

The authors would like to thank Stealth Peptides International Inc. for providing us with MTP-131 and a research grant. The present study was supported by the Zhejiang Provincial Natural Science Foundation of China (grant nos. LQ15H120001 and LY12H12008) and the National Natural Science Foundation of China (grant no. 81372930).

\section{References}

1. Bhat AH, Dar KB, Anees S, Zargar MA, Masood A, Sofi MA and Ganie SA: Oxidative stress, mitochondrial dysfunction and neurodegenerative diseases; a mechanistic insight. Biomed Pharmacother 74: 101-110, 2015.

2. Thanan R, Oikawa S, Hiraku Y, Ohnishi S, Ma N, Pinlaor S, Yongvanit P, Kawanishi S and Murata M: Oxidative stress and its significant roles in neurodegenerative diseases and cancer. Int J Mol Sci 16: 193-217, 2014.

3. Bonilha VL, Rayborn ME, Yang X, Xie C and Cai H: Oxidative stress regulation by DJ-1 in the retinal pigment epithelium. Adv Exp Med Biol 801: 649-654, 2014.

4. Wu Y, Tang L and Chen B: Oxidative stress: Implications for the development of diabetic retinopathy and antioxidant therapeutic perspectives. Oxid Med Cell Longev 2014: 752387, 2014.

5. Pinazo-Durán MD, Gallego-Pinazo R, García-Medina JJ, Zanón-Moreno V, Nucci C, Dolz-Marco R, Martínez-Castillo S, Galbis-Estrada C, Marco-Ramírez C, López-Gálvez MI, et al: Oxidative stress and its downstream signaling in aging eyes. Clin Interv Aging 9: 637-652, 2014

6. Campochiaro PA, Strauss RW, Lu L, Hafiz G, Wolfson Y, Shah SM, Sophie R, Mir TA and Scholl HP: Is there excess oxidative stress and damage in eyes of patients with retinitis pigmentosa? Antioxid Redox Signal 23: 643-648, 2015.

7. Zhao K, Zhao GM, Wu D, Soong Y, Birk AV, Schiller PW and Szeto HH: Cell-permeable peptide antioxidants targeted to inner mitochondrial membrane inhibit mitochondrial swelling, oxidative cell death, and reperfusion injury. J Biol Chem 279: 34682-34690, 2004
8. Zhao K, Luo G, Zhao GM, Schiller PW and Szeto HH: Transcellular transport of a highly polar $3+$ net charge opioid tetrapeptide. J Pharmacol Exp Ther 304: 425-432, 2003.

9. Zhao K, Luo G, Giannelli S and Szeto HH: Mitochondria-targeted peptide prevents mitochondrial depolarization and apoptosis induced by tert-butyl hydroperoxide in neuronal cell lines. Biochem Pharmacol 70: 1796-1806, 2005.

10. Szeto HH: Mitochondria-targeted peptide antioxidants: Novel neuroprotective agents. AAPS J 8: E521-E531, 2006.

11. Iizuka Y, Hong S, Kim CY, Kim SK and Seong GJ: Agmatine pretreatment protects retinal ganglion cells (RGC-5 cell line) from oxidative stress in vitro. Biocell 32: 245-250, 2008.

12. Shimazawa M, Nakajima $Y$, Mashima $Y$ and Hara $H$ : Docosahexaenoic acid (DHA) has neuroprotective effects against oxidative stress in retinal ganglion cells. Brain Res 1251: 269-275, 2009.

13. Chen M, Liu B, Gao Q, Zhuo Y and Ge J: Mitochondria-targeted peptide MTP-131 alleviates mitochondrial dysfunction and oxidative damage in human trabecular meshwork cells. Invest Ophthalmol Vis Sci 52: 7027-7037, 2011.

14. Koriyama Y, Ohno M, Kimura T and Kato S: Neuroprotective effects of 5-S-GAD against oxidative stress-induced apoptosis in RGC-5 cells. Brain Res 1296: 187-195, 2009.

15. Zhou X, Su CF, Zhang Z, Wang CY, Luo JQ, Zhou XW, Cai L, Yan L, Zhang W and Luo HM: Neuroprotective effects of methyl 3,4-dihydroxybenzoate against $\mathrm{H}_{2} \mathrm{O}_{2}$-induced apoptosis in RGC-5 cells. J Pharmacol Sci 125: 51-58, 2014.

16. Jia WC, Liu G, Zhang CD and Zhang SP: Formononetin attenuates hydrogen peroxide $\left(\mathrm{H}_{2} \mathrm{O}_{2}\right)$-induced apoptosis and NF- $\mathrm{NB}$ activation in RGC-5 cells. Eur Rev Med Pharmacol Sci 18: 2191-2197, 2014.

17. Wang R, Peng L, Zhao J, Zhang L, Guo C, Zheng W and Chen $\mathrm{H}$ : Gardenamide A protects $\mathrm{RGC}-5$ cells from $\mathrm{H}_{2} \mathrm{O}_{2}$-induced oxidative stress insults by activating PI3K/Akt/eNOS signaling pathway. Int J Mol Sci 16: 22350-22367, 2015.

18. Zhang P, Huang C, Wang W and Wang M: Early changes in staurosporine-induced differentiated RGC-5 cells indicate cellular injury response to nonlethal blue light exposure. Photochem Photobiol Sci 14: 1093-1099, 2015.

19. Ding W, Shang L, Huang JF, Li N, Chen D, Xue LX and Xiong K: Receptor interacting protein 3-induced RGC-5 cell necroptosis following oxygen glucose deprivation. BMC Neurosci 16: 49, 2015.

20. Sippl C and Tamm ER: What is the nature of the RGC-5 cell line? Adv Exp Med Biol 801: 145-154, 2014.

21. Al-Ubaidi MR: RGC-5: Are they really 661W? The saga continues. Exp Eye Res 119: 115, 2014.

22. Mao H, Seo SJ, Biswal MR, Li H, Conners M, Nandyala A, Jones K, Le YZ and Lewin AS: Mitochondrial oxidative stress in the retinal pigment epithelium leads to localized retinal degeneration. Invest Ophthalmol Vis Sci 55: 4613-4627, 2014.

23. Birk AV, Chao WM, Bracken C, Warren JD and Szeto HH: Targeting mitochondrial cardiolipin and the cytochrome c/cardiolipin complex to promote electron transport and optimize mitochondrial ATP synthesis. Br J Pharmacol 171: 2017-2028, 2014.

24. Szeto HH: First-in-class cardiolipin-protective compound as a therapeutic agent to restore mitochondrial bioenergetics. Br J Pharmacol 171: 2029-2050, 2014.

25. Wu J, Zhang M, Hao S, Jia M, Ji M, Qiu L, Sun X, Yang J and Li K: Mitochondria-targeted peptide reverses mitochondrial dysfunction and cognitive deficits in sepsis-associated encephalopathy. Mol Neurobiol 52: 783-791, 2015.

26. Ajith TA and Jayakumar TG: Mitochondria-targeted agents: Future perspectives of mitochondrial pharmaceutics in cardiovascular diseases. World J Cardiol 6: 1091-1099, 2014.

27. Birk AV, Liu S, Soong Y, Mills W, Singh P, Warren JD, Seshan SV, Pardee JD and Szeto HH: The mitochondrial-targeted compound SS-31 re-energizes ischemic mitochondria by interacting with cardiolipin. J Am Soc Nephrol 24: 1250-1261, 2013. 